\title{
Voltage-gated potassium channels in multiple sclerosis: Overview and new implications for treatment of central nervous system inflammation and degeneration
}

\author{
Susan I. V. Judge, PhD; ${ }^{1-3 *}$ Jennifer M. Lee, BS $;^{2}$ Christopher T. Bever Jr, MD; ${ }^{1-3}$ Paul M. Hoffman, MD $^{1-3}$ \\ ${ }^{1}$ Department of Veterans Affairs (VA) Multiple Sclerosis Center of Excellence East, Baltimore, MD; ${ }^{2}$ VA Maryland \\ Health Care System, Baltimore VA Medical Center, Baltimore, $M D ;{ }^{3}$ Department of Neurology, University of Mary- \\ land School of Medicine, Baltimore, MD
}

\begin{abstract}
Inflammatory tissue damage and the presence of reactive immunocompetent $\mathrm{T}$ lymphocytes, macrophages, microglia, and dendritic cells (DCs) are characteristic features in the human chronic inflammatory demyelinating disease, multiple sclerosis (MS). Together, these cells orchestrate the inflammation and immunopathogenesis underlying the MS autoimmune disease processes and all up-regulate the same voltage-gated potassium $\left(\mathrm{K}_{\mathrm{v}}\right)$ channel, $\mathrm{K}_{\mathrm{v}} 1.3$, when fully activated. Only microglia, which mediate central nervous system (CNS) inflammatory processes (possibly playing a dual role of CNS protection and mediation of neuroinflammation/ neurodegeneration), and DC, which are pivotal to the induction of T cell responses, express the distinct $\mathrm{K}_{\mathrm{v}} 1.5$ prior to $\mathrm{K}_{\mathrm{v}} 1.3$ upregulation. Although the precise functional roles of first $\mathrm{K}_{\mathrm{v}} 1.5$ and then $\mathrm{K}_{\mathrm{v}} 1.3$ channels are unclear, their differential expression is likely a common mechanism used by both microglia and DC, revealing $\mathrm{K}_{\mathrm{v}} 1.5$ (in addition to $\mathrm{K}_{\mathrm{v}} 1.3$ ) as a potentially important target for the development of new immunomodulatory therapies in MS.
\end{abstract}

Key words: 3,4 diaminopyridine, 4-aminopyridine, bloodbrain barrier, central nervous system, dendritic cells, experimental allergic encephalomyelitis, multiple sclerosis, murine leukemia virus, voltage-gated potassium channels.

\section{INTRODUCTION}

Multiple sclerosis (MS) is a chronic and progressive neurodegenerative disease for which no cure exists. Considered a primary inflammatory disease of central nervous system (CNS) white matter, pathological lesions in MS are characterized by inflammatory demyelination with relative sparing of axons [1], perivascular/parenchymal infiltration of $\mathrm{T}$ lymphocytes ( $\mathrm{T}$ cells) and macrophages

\footnotetext{
Abbreviations: 3,4-DAP $=3,4$ diaminopyridine, 4-AP $=4$ aminopyridine, $\mathrm{BBB}=$ blood-brain barrier, $\mathrm{CD}=$ clusters of differentiation, CNS $=$ central nervous system, $\mathrm{CSF}=$ cerebrospinal fluid, DC = dendritic cell, EAE = experimental allergic encephalomyelitis, EAN = experimental allergic neuritis, $\mathrm{IL}=$ interleukin, $\mathrm{K}_{\mathrm{ir}}=$ inward rectifying potassium (channel), $\mathrm{K}_{\mathrm{v}}=$ voltage-gated potassium channel, $\mathrm{MBP}=$ myelin basic protein, $\mathrm{MHC}$ II = major histocompatibility class II, MS = multiple sclerosis, $\mathrm{MuLV}=$ murine leukemia virus, $\mathrm{NADPH}=$ nicotinamide adenosine dinucleotide phosphate, $\mathrm{NO}=$ nitric oxide, NOS = NO synthase, $\mathrm{PNS}=$ peripheral nervous system, $\mathrm{T}$ cells $=\mathrm{T}$ lymphocytes .

${ }^{*}$ Address all correspondence to Susan I. V. Judge, PhD; Department of Neurology, University of Maryland School of Medicine, BRB 12-040, 655 West Baltimore Street, Baltimore, Maryland 21201; 410-706-4481; fax: 410-706-0186. Email: sjudge@umaryland.edu

DOI: 10.1682/JRRD.2004.09.0116
} 
[1-3], and proliferation and activation of resident microglia and astrocytes [4], as well as peripheral dendritic cells (DCs) [5]. In addition to inflammation and demyelination (white and gray matter), axonal damage and loss are now recognized as contributing to irreversible deficits in MS [6]. Clinical symptoms include blurred vision, unstable balance, poor coordination, tremors, numbness, and slurred speech, for which the underlying physiological impairment is believed to be conduction block arising from demyelination and inflammation.

Current approaches to treating MS patients include symptomatic treatment of neurological deficits and immunomodulatory therapy to treat neuroinflammation and possibly limit neurodegeneration. Voltage-gated potassium $\left(\mathrm{K}_{\mathrm{v}}\right)$ channels are potential targets for both types of therapies. As symptomatic therapies, only two relatively nonspecific blockers of $\mathrm{K}_{\mathrm{v}}$ channels, 4-aminopyridine (4-AP) and 3,4 diaminopyridine (3,4-DAP), have been tested clinically for their efficacy in the treatment of patients with MS [7-15]. To date, in vivo immunosuppressive treatments that use nonspecific (4-AP and quinidine) and various highly selective $\mathrm{K}_{\mathrm{v}}$ channel blockers (margatoxin, correolide, kaliotoxin, ShK, and ShDap22) have been restricted to miniswine [16-17] and rodent experimental allergic encephalomyelitis (EAE) [18-20] animal models for MS.

The first study implicating a $\mathrm{K}_{\mathrm{v}}$ blocker (quinidine) as a successful therapeutic treatment in an inflammatory demyelinating disease was an animal model performed in rats with experimental allergic neuritis (EAN), an accepted animal model for the human Guillain-Barre syndrome that is the peripheral nervous system (PNS) counterpart of EAE in the CNS. Mix and colleagues demonstrated that injecting EAN rats with quinidine ameliorated symptoms of clinical EAN [21]. These neurological benefits were accompanied with reduced inflammatory infiltrates in target tissue but not improved peripheral nerve conduction, thus foreshadowing the emerging view that $\mathrm{K}_{\mathrm{v}}$ blockers may primarily exert their neurological benefits in MS through immunomodulatory effects.

\section{TARGETING $\mathrm{K}_{\mathrm{V}}$ CHANNELS AS SYMPTOMATIC TREATMENT IN MULTIPLE SCLEROSIS}

The original clinical rationale for using $\mathrm{K}_{\mathrm{v}}$ channel blockers to improve neurological function in the symp- tomatic treatment of patients with MS stemmed from physiological demonstrations in the PNS in which blocking paranodal or internodal $\mathrm{K}_{\mathrm{v}}$ channels prolonged action potential and potentiated synaptic transmission [22-25]. Many intact nonconducting axons in MS lesions can but do not conduct because their safety factor for conduction is fractionally below unity [26]. The recruitment of such axons by simply reducing body temperature [27] or changing serum-ionized calcium [28] raised hope that many more axons could be recruited pharmacologically with the use of $\mathrm{K}_{\mathrm{v}}$ channel blockers. Waxman gives a current review of underlying disease processes and neuronal injury in MS [29]. Judge and Bever provide a current review of $\mathrm{K}_{\mathrm{v}}$ channels as symptomatic targets in MS [30].

Although clearly beneficial, both 4-AP and 3,4-DAP are potent convulsants with narrow therapeutic windows that have limited their widespread clinical use in MS treatments. Toxic, epileptogenic side effects likely arise from the indiscriminate blockade of widely distributed and varied CNS $K_{v}$ channels rather than $K_{v}$ channels along demyelinated nerve fibers. Initially, the clinical improvements achieved in MS patients with 4-AP primarily were viewed as likely arising from blockage of $\mathrm{K}_{\mathrm{v}}$ channels exposed on demyelinated nodes. In an experimental in vitro CNS study, Perreault and Avoli showed that seizure induction by 4-AP results from block of a synaptic channel [31]. More recently, Smith et al. undertook the first and only in vivo CNS studies in rats of 4-AP on experimental demyelination [26]. Their studies indicated that clinical doses of 4-AP probably produced beneficial neurological effects, not by blocking $\mathrm{K}_{\mathrm{v}}$ channels in demyelinated axons, but by blocking $\mathrm{K}_{\mathrm{v}}$ channels that promote synaptic transmission and increase skeletal muscle twitch tension, independent of demyelination. Understanding the clinical/therapeutic effects of 4-AP is complicated: (1) 4-AP blocks a wide variety of $\mathrm{K}_{\mathrm{v}}$ channels that are distributed across multiple cell types in the CNS (neurons and microglia) and in the immune system (T cells, macrophages, and DCs) and (2) the molecular identities of the $\mathrm{K}_{\mathrm{v}}$ channels actually targeted by 4-AP, clinically, remain unknown.

\section{$\mathrm{K}_{\mathrm{V}}$ CHANNELS IN IMMUNE CELLS INTEGRAL TO MULTIPLE SCLEROSIS}

Together, reactive immunocompetent $\mathrm{T}$ cells, macrophages, microglia, and DCs orchestrate the inflammation and immunopathogenesis underlying MS autoimmune 
disease processes. Each immune cell type is characterized by a cell-specific repertoire of ionic channels, a statespecific/differential expression of distinct $K_{v}$ channels (Figure 1).

Macrophages are involved in chemotaxis, active myelin breakdown, phagocytosis of myelin proteins, myelin antigen presentation, and cytokine secretion. Microglia mediate proinflammatory immune responses, generate nitric oxide (NO)/elevated NO synthase (NOS) in MS lesions, and are active in myelin breakdown, phagocytosis of myelin proteins, and myelin antigen presentation. DCs initiate and regulate $\mathrm{T}$ cell responses and may contribute to inflammation relapses and chronicity and breakdown of tolerance to autoantigens.

Activated, immunocompetent T cells [18-19,32-37], macrophages [38-39], microglia [40-46], and DCs [47] up-regulate the same $\mathrm{K}_{\mathrm{v}}$ channel, $\mathrm{K}_{\mathrm{v}} 1.3$. Resting DCs [48], macrophages [49-54], and microglia [41,55-56] transiently exhibit an inwardly rectifying $\mathrm{K}_{\mathrm{v}}$ channel $\left(\mathrm{K}_{\mathrm{ir}}\right)$. However, only DCs [48,57] and microglia [58] express the distinct $\mathrm{K}_{\mathrm{v}} 1.5$ channel in addition to $\mathrm{K}_{\mathrm{v}} 1.3$ following stimulation; microglia express $\mathrm{K}_{\mathrm{v}} 1.5$ between their unstimulated and fully activated states, but DCs express a mix with $\mathrm{K}_{\mathrm{v}} 1.5$ predominant. While murine bone marrow-derived macrophages have been shown to express $\mathrm{K}_{\mathrm{v}} 1.5$ messenger ribonucleic acid [39], to date, no $\mathrm{K}_{\mathrm{v}} 1.5$ currents have been recorded in macrophages. Figure 2 outlines functional roles of various potassium channels in T cells, macrophages, microglia, and DCs.
Apart from the known central role of cell-mediated immune responses in MS, accumulating evidence indicates that humoral immune responses (i.e., effector B lymphocytes) may also contribute to the pathogenesis of MS. Such evidence includes the identification of antimyelin antibodies in MS lesions, serum and cerebrospinal fluid (CSF) [59-63], and clinical observations consistent with antibody-mediated demyelination in an MS patient [64]. Furthermore, serum antimyelin antibodies in patients initially presenting with a clinically isolated syndrome may predict early conversion to clinically definite MS [65-66]. While the clinical and pathological significance of antimyelin antibodies in MS remains to be definitively characterized, activated B cells, like T cells, macrophages, microglia, and DCs, also up-regulate $\mathrm{K}_{\mathrm{v}} 1.3$ channels that are already recognized as putative therapeutic targets in MS. First recorded in B cells by Choquet and Korn [67-68], $\mathrm{K}_{\mathrm{v}} 1.3$ currents have been shown to be functionally important [69-75], indicating that B cells may constitute yet another immune cell target for putative immunomodulatory therapies designed to act via effects on $\mathrm{K}_{\mathrm{v}} 1.3$ channels.

\section{TARGETING $\mathrm{K}_{\mathbf{V}}$ CHANNELS AS IMMUNOSUPPRESSIVE THERAPY}

While the toxic, epileptogenic side effects resulting from 4-AP likely arise from the indiscriminate blockade
T Lymphocytes (T Cells)

$-\mathrm{K}_{\mathrm{Ca}} 3.1$ (intermediate $\mathrm{K}_{\mathrm{Ca}}$, IKCa1, IK1, SK4 or KCNN4)

$-\mathrm{K}_{\mathrm{Ca}} 2.2$ (small $\mathrm{K}_{\mathrm{Ca}}, \mathrm{SK} 2$, or KCNN2)

$-\mathrm{K}_{\mathrm{v}} 1.3$ (delayed rectifier, $\mathrm{Kv} 1.3$, or KCNA3)

\section{Macrophage}

$-\mathrm{K}_{\mathrm{ir}} 2.1$ (inward rectifier, IRK1 or, $\mathrm{KCNJ} 2$ )

$-\mathrm{K}_{\mathrm{Ca}} 3.1$ (intermediate $\mathrm{K}_{\mathrm{Ca}}$, IKCa1, IK1, SK4, or KCNN4)

- $\mathrm{K}_{\mathrm{Ca}} 1.1$ (large $\mathrm{K}_{\mathrm{Ca}}$, BK, maxi $\mathrm{K}$, or KCNMA1)

$-\mathrm{K}_{\mathrm{v}} 1.3$ (delayed rectifier, $\mathrm{Kv} 1.3$, or KCNA3)

\section{Microglia}

$-\mathrm{K}_{\mathrm{ir}} 2.1$ (inward rectifier, IRK1, or KCNJ2)

$-\mathrm{K}_{\mathrm{Ca}} 3.1$ (intermediate $\mathrm{K}_{\mathrm{Ca}}$; IKCa1, IK1, SK4, or KCNN4)

- $\mathrm{K}_{\mathrm{Ca}} 1.1$ (large $\mathrm{K}_{\mathrm{Ca}}, \mathrm{BK}$, maxi K, or KCNMA1)

$-\mathrm{K}_{\mathrm{v}} 1.5$ (delayed rectifier, Kv1.5, or KCNA5)

$-\mathrm{K}_{\mathrm{v}} 1.3$ (delayed rectifier, $\mathrm{Kv} 1.3$, or KCNA3)

$-\mathrm{K}_{\mathrm{v}}$ 11.1-like (HERG-like or $\mathrm{KCNH} 2$-like)

\section{Dendritic Cells}

$-\mathrm{K}_{\text {ir }}$ (inward rectifier likely to be $\mathrm{K}_{\mathrm{ir}} 2.1$ )

$-\mathrm{K}_{\mathrm{v}} 1.5$ (delayed rectifier, Kv1.5, or KCNA5)

$-\mathrm{K}_{\mathrm{v}} 1.3$ (delayed rectifier, $\mathrm{Kv} 1.3$, or KCNA3)

Figure 1.

Complement of distinct voltage-gated potassium $\left(\mathrm{K}_{\mathrm{v}}\right)$ channels expressed in immune cells integral to multiple sclerosis. The 2002 International Union of Pharmacology (IUPHAR) and American Society for Pharmacology and Experimental Therapeutics standardized nomenclature for $\mathrm{K}_{\mathrm{v}}$ channels is used. Earlier $\mathrm{K}_{\mathrm{v}}$ channel names and Human Gene nomenclature developed by Human Genome Organization are listed in parentheses. For a more detailed listing of earlier names and standardized nomenclatures, check IUPHAR Web site (http://www.iuphar-db.org/iuphar-ic/) and Judge SI, Bever CT Jr. Potassium channel blockers in multiple sclerosis: Neuronal K(v) channels and effects of symptomatic treatment. Pharmacol Ther. Epub 2006 Feb 8. [PMID: 16472864] 


\section{T Lymphocytes (T Cells) ${ }^{*}$}

-Interplay controls calcium entry by opposing depolarization [1]

$-\mathrm{K}_{\mathrm{v}} 1.3$ blockade inhibits interleukin 2 secretion, proliferation, effector cell function [2-17]

\section{Macrophage $^{\dagger}$}

$-\mathrm{K}_{\mathrm{ir}} 2.1$ correlates with adherence/differentiation; sets resting membrane potential $\left(R_{m}\right)$; restores $R_{m}$ after hyperpolarization [18-24]

$-\mathrm{K}_{\mathrm{Ca}} 3.1$ (intermediate $\mathrm{K}_{\mathrm{Ca}}$ ) underlies spontaneous membrane hyperpolarizations; opens with stimulus-induced rises in intracellular calcium $\left(\mathrm{Ca}^{++}\right)$[25-29]

$-\mathrm{K}_{\mathrm{Ca}} 1.1$ (large $\mathrm{K}_{\mathrm{Ca}}$ ) expression correlates with monocyte-to-macrophage maturation; activates with rises in intracellular $\mathrm{Ca}^{++}$and depolarization [20]; blockade inhibits lipopolysaccharide (LPS) signaling [30]

$-\mathrm{K}_{\mathrm{v}} 1.3$ sets $R_{m}$; restores $R_{m}$ after depolarization [18,20,31-32]

-LPS and TNF- $\alpha$ regulate macrophage activation: $\uparrow \mathrm{K}_{\mathrm{v}} 1.3$ and $\downarrow \mathrm{K}_{\mathrm{ir}} 2.1$ expression $[18,33]$

$-\mathrm{K}_{\mathrm{Ca}} 1.1$ (large $\mathrm{K}_{\mathrm{Ca}}$ ) and $\mathrm{K}_{\mathrm{Ca}} 2.2\left(\right.$ small $\mathrm{K}_{\mathrm{Ca}}$ ) invloved in migration/infiltration [33]

$-\mathrm{K}_{\mathrm{v}} 1.3$ not required for $\mathrm{Fe}$ receptor-mediated phagocytosis [18]

\section{Microglia ${ }^{*}$}

-Blockade $\mathrm{K}_{\mathrm{Ca}} 2.2\left(\right.$ small $\left.\mathrm{K}_{\mathrm{Ca}}\right)>\mathrm{K}_{\mathrm{Ca}} 3.1$ (intermediate $\left.\mathrm{K}_{\mathrm{Ca}}\right)>\mathrm{K}_{\mathrm{v}} 1.3$ inhibits phorbol ester-stimulated respiratory burst [41]

-Differential expression $\mathrm{K}_{\mathrm{ir}} 2.1$ in resting [119], $\mathrm{K}_{\mathrm{v}} 1.5$ in nonproliferating and $\mathrm{K}_{\mathrm{v}} 1.3$ activate/proliferating [42]

$-\mathrm{K}_{\mathrm{v}} 1.3$ up-regulation associated with NADPH-mediated respiratory burst (products in MS), activation by ganulocyte-macrophage colonystimulating factor or interferon- $\gamma$, deactivation by transforming growth factor- $\beta$ [43]

$-\mathrm{K}_{\mathrm{Ca}} 3.1$ (intermediate $\mathrm{K}_{\mathrm{Ca}}$ ) underlies activation-induced transient membrace hyperpolarization [44] and microglial migration [45]

\section{Dendritic Cells}

-Differential expression $\mathrm{K}_{\mathrm{ir}}$ (likely $\mathrm{K}_{\mathrm{ir}} 2.1$ ) in resting, $\mathrm{K}_{\mathrm{v}} 1.5$ in nonproliferating and $\mathrm{K}_{\mathrm{v}} 1.3$ in activate/proliferating [46-48]

-Antigen presentation/T cell modulation?

\section{Figure 2.}

Known function roles of distinct voltage-gated potassium $\left(\mathrm{K}_{\mathrm{v}}\right)$ channels in immune cells integral to multiple sclerosis (MS). Reference numbers refer to Appond $\mathbf{A x}$, available online only at www.rehab.research.va.gov.

${ }^{*}$ For review, see Chandy KG, Wulff $\mathrm{H}$, Beeton $\mathrm{C}$, Pennington $\mathrm{M}$, Gutman GA, Cahalan MD. $\mathrm{K}^{+}$channels as targets for specific immunomodulation. Trends Pharmacol Sci. 2004;25(5):280-89 [PMID: 15120495] and Gallin EK. Ion channels in leukocytes. Physiol Rev. 1991;71(3):775-811. [PMID: 1711700]

${ }^{\dagger}$ For review, see Gallin EK. Calcium- and voltage-activated potassium channels in human macrophages. Biophys J. 1984;46(6):821-25 [PMID: 6097318] and Gallin EK. Ion channels in leukocytes. Physiol Rev. 1991;71(3):775-811. [PMID: 1711700]

${ }^{\ddagger}$ For review, see Eder C. Ion channels in microglia (brain macrophages). Am J Physiol. 1998;275(2 Pt 1):C327-42. [PMID: 9688586], Eder C. Regulation of microglial behavior by ion channel activity. J Neurosci Rev. 2005;81(3):314-21 [PMID: 1592907], and Farber K, Kettenmann H. Physiology of microglial cells. Brain Res Rev. 2005;48(2):133-43. [PMID: 15850652]

$\mathrm{NADPH}=$ nicotinamide adenosine dinucleotide phosphate, TNF- $\alpha=$ tumor necrosis factor $\alpha$.

of various CNS $\mathrm{K}_{\mathrm{v}}$ channels, blockade of 4-AP-sensitive $\mathrm{K}_{\mathrm{V}}$ channels in immune cells has emerged as a promising candidate because of its neurological benefits. Beneficial 4-AP effects could arise not only from blockade of CNS synaptic channels [26] but also from effects on microglia $[43,58]$ and/or T cells [33-34]. Notably, the $K_{v} 1.3$ is the predominant $\mathrm{K}_{\mathrm{v}}$ channel in both activated $\mathrm{T}$ cells $[34,76]$ and activated microglia [58]. The identification of $\mathrm{K}_{\mathrm{v}} 1.3$ in mature antigen-presenting DCs [47] implicates these cells as an additional likely candidate contributing to the beneficial neurological effects of 4-AP or 3,4-DAP treatment in MS patients. Recently, high $\mathrm{K}_{\mathrm{v}} 1.3$ expression was demonstrated in the perivenular and parenchymal inflammatory infiltrates in postmortem MS brain, as well as on CSF T cells from MS patients [77].

\section{T Cells}

Studies of $\mathrm{K}_{\mathrm{v}} 1.3$ in activated $\mathrm{T}$ cells predate the cloning of $K_{v}$ channels. Dating back to the mid-1980s, the first recordings in human peripheral blood $\mathrm{T}$ cells showed inhibition of mitogen-stimulated activation by nonspecific $\mathrm{K}_{\mathrm{v}}$ channel blockers [32-33,37]. This finding was followed by the first studies in myelin basic protein (MBP)-reactive rat $\mathrm{T}$ cells [35-36,78-80] and the first demonstration that 4-AP and other nonspecific $\mathrm{K}_{\mathrm{v}}$ channel blockers (e.g., tetraethylammonium, methoxyverapamil) could inhibit the adoptive transfer of relapsingremitting EAE in rats [35-36,80].

More recent studies have determined the molecular identities of $T$ cell $K_{v}$ channels and shown differential expression of these channels in response to acute versus 
chronic MBP stimulation [18-19,81]. Considerable advances have been made in identifying potent toxins $[34,79,82-83]$ that are highly selective blockers for the T cell $\mathrm{K}_{\mathrm{v}} 1.3$ channel, with better selectivity/potency profiles and experimental therapeutic effects [18-19] than 4-AP [35-36,78,80]. While proving successful, systemic administration of highly selective $\mathrm{K}_{\mathrm{v}} 1.3$ blocking agents in EAE still has not shown whether it produces beneficial neurological effects by blocking $\mathrm{K}_{\mathrm{v}} 1.3$ in $\mathrm{T}$ cells, microglia, macrophages, neurons, and/or DCs.

\section{Dendritic Cells}

DCs are a major component of the innate immune system and play a pivotal role in the adaptive immune response by providing necessary costimulatory signals for the induction of $\mathrm{T}$ cell responses, surface-expressed complexes of antigen peptide, and major histocompatibility class II (MHC II) molecules. Immature DCs are proficient at antigen endocytosis and processing but poor at stimulating $\mathrm{T}$ cells. Terminally mature DCs are proficient antigen-presenting cells highly specialized for stimulating $\mathrm{T}$ cells to initiate antigen-specific effector cell function [84-85]. During the functional maturation process, in response to inflammatory or microbial stimuli, changes occur in the profile of DC surface markers and cellular immune functions that define distinct immature versus mature immunofunctional phenotypes. $\mathrm{K}_{\mathrm{v}}$ channels number among state-specific up-regulated transmembrane proteins known to play prominent roles in the cellular activation of a wide variety of immune system cells of both lymphoid and myeloid lineage.

In spite of the importance of DCs as immunoregulators of $\mathrm{T}$ cells, studies of $\mathrm{DC} \mathrm{K}_{\mathrm{v}}$ channels have only just begun. The presence of functioning $\mathrm{K}_{\mathrm{v}} 1.3$ channels [47] was first described in murine DCs that were terminally matured and exhibited a high surface-membrane expression of MHC II molecules. Studies are currently under way examining human DCs throughout the full process maturation. Preliminary results indicated that a sequential and state-specific up- and down-regulation of three distinct $\mathrm{K}_{\mathrm{v}}$ channels: first $\mathrm{K}_{\mathrm{ir}}$, followed by $\mathrm{K}_{\mathrm{v}} 1.5$, and ultimately $K_{v} 1.3$ [57]. More detailed studies have since revealed that stimulated DCs express a mix of both $\mathrm{K}_{\mathrm{v}} 1.3$ and $\mathrm{K}_{\mathrm{v}} 1.5$ channels, with $\mathrm{K}_{\mathrm{v}} 1.5$ predominating in matured DCs. Furthermore, these studies demonstrated that blockade of $\mathrm{K}_{\mathrm{v}} 1.3$ and $\mathrm{K}_{\mathrm{v}} 1.5$ impaired clusters of differentiation 83 (CD83), CD80, and CD86 up-regulation and interleukin 12 (IL12) and IL6 production, indicating that these channels play a functional role in DC maturation [48]. DCs are attractive alternate MS therapeutic targets to $\mathrm{T}$ cells for two reasons. First, DC stimulation and maturation precede DC-initiated stimulation of $\mathrm{T}$ cells. Second, DCs constitute a peripheral systemic (CSF, meninges, choroid plexus, and deep cervical lymph nodes), as well as a CNS (MS lesions) target for the development of future clinical treatments in MS. Thus, targeting select DC $\mathrm{K}_{\mathrm{v}}$ channels to interfere with DC maturation may offer an early and unique opportunity to inhibit $\mathrm{T}$ cell effector function by aborting the induction of $\mathrm{T}$ cells as autoimmune effector cells in MS.

\section{TARGETING $\mathrm{K}_{\mathrm{V}}$ CHANNELS AS ANTI- INFLAMMATORY THERAPY}

The hallmark of neuroinflammation is a microglial or microglial/macrophage response that has been observed in several neurodegenerative diseases, including MS, making it reasonable to consider anti-inflammatory therapy for MS to inhibit microglial activation. Specifically, clinical benefits following anti-inflammatory treatment have been demonstrated in mice with a genetic motor-neuron disease in which microglia are prominent [86-88]. In another model of neuroinflammatory disease, PVC-211 murine leukemia virus (MuLV)-induced spongiform neurodegenerative disease in rats, a highly reactive microglial/macrophage response is associated with severe freeradical injury, motor neuron injury, and death. Vitamin E pretreatment of rat pups delays the appearance of free-radical injury and delays but does not inhibit disease expression [89]. Furthermore, minocycline, an antibiotic with inhibitory effects on macrophages and microglia, inhibits the reactive microglial/macrophage response and delays the expression of PVC-211 MuLV disease [90] and is effective in slowing the disease course in superoxide dismustase (SODI) ${ }^{\text {G93a }}$ mutant motor-neuron disease [88]. The presumed mechanism is inhibition of microglial/macrophage function. More recently, the cycloxygenase-2 inhibitor celecoxib has been effective in slowing the disease course in SOD1 ${ }^{\mathrm{G} 93 \mathrm{a}}$ mice. This has led to an ongoing clinical trial of this compound in patients with Lou Gehrig's disease. While these broadly reactive anti-inflammatory compounds may show partial effects in animal models and, we hope, in clinical trials, a need clearly exists for more targeted therapy. Thus, microglial and/or 
macrophage $K_{v}$ channels may represent a possible target for intervention.

Of the immune system cells considered integral to MS autoimmune processes, the study of $\mathrm{K}_{\mathrm{v}} 1.3$ in activated microglia and macrophages has only recently garnered attention. Microglia play a central role in mediating CNS inflammatory processes and as the only resident brain immune system cells, activated microglia can proliferate, migrate to sites of injury, present antigen, phagocytize, secrete proinflammatory cytokines and cytotoxins, and undergo a nicotinamide adenosine dinucleotide phosphate (NADPH)-mediated respiratory burst producing cytotoxic reactive oxygen and nitrogen species.

Three lines of evidence suggest a central role for microglia in the disease processes leading to demyelination and irreversible axonal damage underlying conduction deficits in MS. First, active MS lesions contain reactive microglia [91-92]. Second, throughout active demyelinating lesions and along the borders of chronic active lesions [93], NOS catalytic activity is elevated, as are levels of NO, a proinflammatory reactive nitrogenfree radical generated by activated microglia [94-99]. Third, NO donors can produce reversible conduction block in normal and experimentally demyelinated axons and morphological changes consistent with acute Wallerian degeneration [100-101]. Thus, reactive microglia and a proinflammatory microglial activation product are implicated in the long-established conduction deficits and newly recognized axonal damage associated with MS.

As seen in other immune system cells ( $T$ cells and macrophages), $\mathrm{K}_{\mathrm{v}}$ channels appear to regulate proliferation and cellular activation in microglia. Two distinct $\mathrm{K}_{\mathrm{v}}$ channels are expressed differentially in microglia: $\mathrm{K}_{\mathrm{v}} 1.5$ in resting, nonproliferating cells and $\mathrm{K}_{\mathrm{v}} 1.3$ in activated, proliferating cells [58,102]. While $\mathrm{K}_{\mathrm{v}} 1.3$ up-regulation has been associated with various effector cell functions following microglial activation [40,44,55], the precise role of $\mathrm{K}_{\mathrm{v}} 1.3$ versus $\mathrm{K}_{\mathrm{v}} 1.5$ channels in microglial function remains unclear. To date, $\mathrm{K}_{\mathrm{v}} 1.3$ up-regulation is associated with granulocyte macrophage-colony stimulating factor, interferon- $\gamma$, and lipopolysaccharidestimulated activation [40,44,55], transforming growth factor- $\beta$ stimulated microglial deactivation [56], and the NADPH-mediated respiratory burst [43], a metabolic cascade, the products of which have been identified in MS [43,103-104].

\section{CONCLUSION: FUTURE POTENTIAL FOR TARGETING $\mathrm{K}_{\mathrm{V}}$ CHANNELS IN MULTIPLE SCLEROSIS}

Two mononuclear phagocytes, CNS microglia and peripheral DC, are critical players in CNS inflammation. As such, microglia and DCs are important immune cell targets for new MS therapies aimed at modulating cell function by blocking $\mathrm{K}_{\mathrm{v}}$ channels. In the CNS, activated microglia are the primary effector cells underlying the immune-mediated pathogenesis of inflammation, demyelination, and breakdown of the blood-brain barrier (BBB) leading to neuronal injury and dysfunction [103]. Peripherally, mature DCs are essential for initiating and regulating primary $\mathrm{T}$ cell responses, which require peripheral stimulation to cross the BBB [105].

Given the known preferential $\mathrm{K}_{\mathrm{v}} 1.3$ up-regulation in effector $\mathrm{T}$ cells, activated microglia and macrophages, and mature DCs, beneficial therapeutic effects resulting from the use of highly selective $\mathrm{K}_{\mathrm{v}} 1.3$ blockers could arise from modulation of any or all of these immune cells. Even though highly selective peptide toxins have been identified that are better blockers of the $\mathrm{K}_{\mathrm{v}} 1.3$ channel than 4-AP or 3,4-DAP, they are, at present, handicapped as viable therapeutics because of their short half-life of approximately 20 min [19]; synthetic toxin analogues are being developed to overcome such limitations [106].

Distinct from $\mathrm{T}$ cells and macrophages following stimulation, microglia up-regulate $\mathrm{K}_{\mathrm{v}} 1.5$ during early stages of cellular activation prior to the up-regulation of $\mathrm{K}_{\mathrm{v}} 1.3$ at terminal stages of activation, while DCs predominantly up-regulate $\mathrm{K}_{\mathrm{v}} 1.5$ over $\mathrm{K}_{\mathrm{v}} 1.3$ in their mature immunocompetent state. Although the precise functional roles of the $\mathrm{K}_{\mathrm{v}} 1.5$ and $\mathrm{K}_{\mathrm{v}} 1.3 \mathrm{~K}_{\mathrm{v}}$ channels remain unclear, their differential expression reveals $\mathrm{K}_{\mathrm{v}} 1.5$ as an earlier and, thereby, potentially more important therapeutic target than $\mathrm{K}_{\mathrm{v}} 1.3$ in microglia, and a primary target in DCs that distinguishes them from $\mathrm{T}$ cells. Studies to modulate the immune and neuroinflammatory response by affecting $\mathrm{K}_{\mathrm{v}} 1.5$ and $\mathrm{K}_{\mathrm{v}} 1.3$ activation are in progress in animal models. Translating these studies to MS offers a new therapeutic approach to this inflammatory neurodegenerative disease.

\section{ACKNOWLEDGMENT}

This material was based on work supported by the Department of Veterans Affairs (VA) MS Center of Excellence East, individual 
VA merit review funding to S. I. V. Judge and C. T. Bever Jr, and separate pilot funding from the VA MS Center of Excellence East and National MS Society pilot grant PP0997 to S. I. V. Judge.

\section{REFERENCES}

1. Prineas JW, Wright RG. Macrophages, lymphocytes, and plasma cells in the perivascular compartment in chronic multiple sclerosis. Lab Invest. 1997;38(4):409-21.

[PMID: 205724]

2. Hauser SL, Bhan AK, Gilles FH, Hoban CJ, Reinherz EL, Schlossman SF, Weiner HL. Immunohistochemical staining of human brain with monoclonal antibodies that identify lymphocytes, monocytes, and the Ia antigen. J Neuroimmunol. 1983;5(2):197-205. [PMID: 6413533]

3. Prineas JW. Pathology of the early lesion in multiple sclerosis. Human Pathol. 1975;6(5):531-54. [PMID: 170186]

4. Raine CS. The Dale E. McFarlin Memorial Lecture: The immunology of the multiple sclerosis lesion. Ann Neurol. 1994;36 Suppl:61-72. [PMID: 8017891]

5. Link H, Huang YM, Masterman T, Xiao BG. Vaccination with autologous dendritic cells: From experimental autoimmune encephalomyelitis to multiple sclerosis. J Neuroimmunol. 2001;114(1-2):1-7. [PMID: 11240009]

6. Lassmann H. Pathology of neurons in multiple sclerosis. In: Waxman SG, editor. Multiple sclerosis as a neuronal disease. Burlington (MA): Elsevier Academic Press; 2005. p. 153-64.

7. Bever CT Jr. 4-Aminopyridine: Use in multiple sclerosis. CNS Drug Rev. 1994;1(2):261-79.

8. Bever CT Jr. Clinical pharmacology of abnormal potassium channel organization in demyelinated axons. In: Waxman SG, editor. Multiple sclerosis as a neuronal disease. Burlington (MA): Elsevier Academic Press; 2005. p. 145-52.

9. Bever CT Jr, Anderson PA, Leslie J, Panitch HS, DhibJalbut S, Khan OA, Milo R, Hebel JR, Conway KL, Katz E, Johnson KP. Treatment with oral 3,4 diaminopyridine improves leg strength in multiple sclerosis patients: Results of a randomized, double-blind, placebo-controlled, crossover trial. Neurology. 1996;47(6):1457-62.

[PMID: 8960727]

10. Bever CT Jr, Leslie J, Camenga D, Panitch HS, Johnson KP. Preliminary trial of 3,4-diaminopyridine in patients with multiple sclerosis. Ann Neurol. 1990;27(4):421-27. [PMID: 2353797]

11. Bever CT Jr, Young D, Anderson PA, Krumholz A, Conway K, Leslie J, Eddington N, Plaisance KI, Panitch HS, Dhib-Jalbut S, Fossler MJ, Devane J, Johnson KP. The effects of 4-aminopyridine in multiple sclerosis patients: Results of a randomized placebo-controlled, double-blind, concentration-controlled crossover trial. Neurology. 1994; 44(6):1054-59. [PMID: 8208399$]$

12. Davis FA, Stefoski DF, Rush J. Orally administered 4-aminopyridine improves clinical signs in multiple sclerosis. Ann Neurol. 1990;27(2):186-92. [PMID: 2317014]

13. Fujihara K, Miyoshi T. The effects of 4-aminopyridine on motor evoked potentials in multiple sclerosis. J Neurol Sci. 1998;159(1):102-6. [PMID: 9700711]

14. Jones RE, Heron JR, Foster DH, Snelgar RS, Mason RJ. Effects of 4-aminopyridine in patients with multiple sclerosis. J Neurol Sci. 1983;60(3):353-62. [PMID: 6631441]

15. Stefoski DF, Davis FA, Faut M, Schauf CL. 4-Aminopyridine improves clinical signs in multiple sclerosis. Ann Neurol. 1987;21(1):71-77. [PMID: 2435223]

16. Koo GC, Blake JT, Shah K, Staruch MJ, Dumont F, Wunderler D, Sanchez M, McManus OB, SirotinaMeisher A, Fischer P, Boltz RC, Goetz MA, Baker R, Bao J, Kayser F, Rupprecht KM, Parsons WH, Tong XC, Ita IE, Pivnichny J, Vincent S, Cunningham P, Hora D Jr, Feeney W, Kaczorowski G, Springer MS. Correolide and derivatives are novel immunosuppressants blocking the lymphocyte Kv1.3 potassium channels. Cell Immunol. 1999;197(2):99-107. [PMID: 10607427]

17. Koo GC, Blake JT, Talento A, Nguyen M, Lin S, Sirotina A, Shah K, Mulvany K, Hora D Jr, Cunningham P, Wunderler DL, McManus OB, Slaughter R, Bugianesi R, Felix J, Garcia M, Williamson J, Kaczorowski G, Sigal $\mathrm{NH}$, Springer MS, Feeney W. Blockade of the voltage gated potassium channel Kv1.3 inhibits immune responses in vivo. J Immunol. 1997;158(11):5120-28.

[PMID: 9164927]

18. Beeton C, Barbaria J, Giraud P, Devaux J, Benoliel AM, Gola M, Sabatier JM, Bernard D, Crest M, Beraud E. Selective blocking of voltage-gated $\mathrm{K}+$ channels improves experimental autoimmune encephalomyelitis and inhibits T cell activation. J Immunol. 2001;166(2):936-44. [PMID: 11145670]

19. Beeton C, Wulff H, Barbaria J, Clot-Faybesse O, Pennington M, Bernard D, Cahalan MD, Chandy KG, Beraud E. Selective blockade of T lymphocyte $\mathrm{K}(+)$ channels ameliorates experimental autoimmune encephalomyelitis, a model for multiple sclerosis. Proc Natl Acad Sci USA. 2001; 98(24):13942-47. [PMID: 11717451]

20. Uitdehaag BM, Polman CH, de Groot CJ, Dijkstra CD. Effect of $\mathrm{K}+$ channel blockers on the clinical course and histological features of experimental allergic encephalomyelitis. Acta Neurol Scand. 1994;90(4):299-301. [PMID: 7839818]

21. Mix E, Olsson T, Solders G, Link H. Effect of ion channel blockers on immune response and course of experimental allergic neuritis. Brain. 1989;112(Pt 6):1405-18. [PMID: 2480831] 
22. Bostock H, Sears TA, Sherratt RM. The effects of 4-aminopyridine and tetraethylammonium ions on normal and demyelinated mammalian nerve fibers. J Physiol. 1981; 313:301-15. [PMID: 7277221]

23. Sherratt RM, Bostock H, Sears TA. Effects of 4-aminopyridine on normal and demyelinated mammalian nerve fibers. Nature. 1980;283(5747):570-72. [PMID: 7354839]

24. Targ EF, Kocsis JD. 4-Aminopyridine leads to restoration of conduction in demyelinated rat sciatic nerve. Brain Res. 1985;328(2):358-61. [PMID: 2985185]

25. Thesleff S. Aminopyridines and synaptic transmission. Neuroscience. 1980;5(8):1413-19. [PMID: 6250099]

26. Smith KJ, Felts PA, John GR. Effects of 4-aminopyridine on demyelinated axons, synapses and muscle tension. Brain. 2000;123(Pt 1):171-84. [PMID: 10611131]

27. Watson CW. Effect of lowering of body temperature on the symptoms and signs of multiple sclerosis. N Engl J Med. 1959;261:1253-59. [PMID: 13843117]

28. Schauf CL, Davis FA. Impulse conduction in multiple sclerosis: A theoretical basis for modification by temperature and pharmacological agents. J Neurol Neurosurg Psychiatry. 1974;37(2):152-61. [PMID: 4362242]

29. Waxman SG. Multiple sclerosis as a neuronal disease. Burlington (MA): Elsevier Academic Press; 2005.

30. Judge SI, Bever CT Jr. Potassium channel blockers in multiple sclerosis: Neuronal K(v) channels and effects of symptomatic treatment. Pharmacol Ther. Epub 2006 Feb 8. [PMID: 16472864$]$

31. Perreault R, Avoli M. Physiology and pharmacology of epileptiform activity induced by 4-aminopyridine in rat hippocampal slices. J Neurophysiol. 1991;65:771-85. [PMID: 1675671$]$

32. Chandy KG, DeCoursey TE, Cahalan MD, McLaughlin C, Gupta S. Voltage-gated potassium channels required for human T lymphocyte activation. J Exp Med. 1984; 160(2):369-85. [PMID: 6088661]

33. DeCoursey TE, Chandy KG, Gupta S, Cahalan MD. Voltage gated $\mathrm{K}+$ channels in human T lymphocytes: A role in mitogenesis. Nature. 1984;307(5950):465-68.

[PMID: 6320007]

34. Grissmer S, Dethlefs B, Wasmuth JJ, Goldin AL, Gutman GA, Cahalan MD, Chandy KG. Expression and chromosomal localization of la lymphocyte $\mathrm{K}+$ channel gene. Proc Natl Acad Sci USA. 1990;87(23):9411-15. [PMID: 2251283]

35. Judge SI, Yeh JZ, Mannie MD, Paterson PY. Potassium channels in T lymphocytes mediating experimental allergic encephalomyelitis (EAE) in rats. Soc Neurosci Abtrs. 1986;12:1342.

36. Judge SI, Yeh JZ, Mannie MD, Paterson PY. Potassium channels in encephalitogenic rat lymphocytes: Characteris- tics of inactivation and role in cell activation. Soc Neurosci Abtrs. 1987;13:531.

37. Matteson DR, Deutsch C. K channels in T lymphocytes: A patch clamp study using monoclonal antibody adhesion. Nature. 1984;307(5950):468-71. [PMID: 6320008]

38. Mackenzie AB, Chirakkal H, North RA. Kv1.3 potassium channels in human alveolar macrophages. Am J Physiol Lung Cell Mol Physiol. 2003;285(4):L862-68. [PMID: 12909584$]$

39. Vicente R, Escalada A, Coma M, Fuster G, Sanchez-Tillo E, Lopez-Iglesias C, Soler C, Solsona C, Celada A, Felipe A. Differential voltage-dependant $\mathrm{K}+$ channel responses during proliferation and activation in macrophages. J Biol Chem. 2003;278(47):46307-20. [PMID: 12923194] Erratum in: J Biol Chem. 2005;280(13):13204.

40. Eder C, Fischer HG, Hadding U, Heinemann U. Properties of voltage-gated potassium currents of microglia differentiated with granulocyte/macrophage colony-stimulating factor. J Membr Biol. 1995;147(2):137-46. [PMID: 8568850]

41. Eder C, Schilling T, Heinemann U, Haas D, Hailer N, Nitsch R. Morphological, immunophenotypical and electrophysiological properties of resting microglia in vitro. Eur J Neurosci. 1999;11(12):4251-61. [PMID: 10594651]

42. Farber K, Kettenmann H. Physiology of microglial cells. Brain Res Brain Res Rev. 2005;48(2):133-43. [PMID: 15850652]

43. Khanna R, Roy L, Zhu X, Schlichter LC. K+ channels and the microglial respiratory burst. Am J Physiol. 2001;280(4): C796-806. [PMID: 11245596]

44. Pyo H, Chung S, Jou I, Gwag B, Joe EH. Expression and function of outward $\mathrm{K}+$ channels induced by lipopolysaccharide in microglia. Mol Cells. 1997;7(5):610-14. [PMID: 9387147]

45. Schilling T, Stock C, Schwab A, Eder C. Functional importance of $\mathrm{Ca} 2+$-activated $\mathrm{K}+$ channels for lysophosphatidic acid-induced microglial migration. Eur J Neurosci. 2004;19(6):1469-74. [PMID: 15066143]

46. McLarnon JG, Xu R, Lee YB, Kim SU. Ion channels of human microglia in culture. Neuroscience. 1997;78(4): 1217-28. [PMID: 9174088]

47. Fischer HG, Eder C. Voltage-gated K+ currents of mouse dendritic cells. FEBS Lett. 1995;373(2):127-30. [PMID: 7589450]

48. Mullen KM, Rozycka M, Hu L, Rus H, Graber J, Pennington MW, Johns DC, Judge SIV, Calabresi PA. Potassium channels Kir, Kv1.5, and Kv1.3 are expressed on human dendritic cells and have a functional role in maturation. Ann Neurol. In press 2006.

49. DeCoursey TE, Kim SY, Silver MR, Quandt FN. Ion channel expression in PMA-differentiated human THP-1 
macrophages. J Membr Biol. 1996;152(2):141-57. [PMID: 9139125]

50. Gallin EK, Livengood DR. Inward rectification in mouse macrophages: Evidence for a negative resistance region. Am J Physiol. 1981;241(1):C9-17. [PMID: 7246764]

51. Gallin EK, McKinney LC. Patch-clamp studies in human macrophages: Single-channel and whole-cell characterization of two K+ conductances. J Membr Biol. 1988; 103(1):55-66. [PMID: 2460627]

52. Gallin EK, Sheehy PA. Differential expression of inward and outward potassium currents in the macrophage-like cell line J774.1. J Physiol. 1985;369:475-99.

[PMID: 2419551]

53. Judge SI, Montcalm-Mazzilli E, Gallin EK. IKir regulation in murine macrophages: Whole cell and perforated patch studies. Am J Physiol. 1994;267(6 Pt 1):C1691-98. [PMID: 7810612]

54. McKinney LC, Gallin EK. Inwardly rectifying whole-cell and single-channel $\mathrm{K}$ currents in the murine macrophage cell line J774.1. J Membr Biol. 1988;103(1):41-53. [PMID: 3184170]

55. Fischer HG, Eder C, Hadding U, Heinemann U. Cytokinedependent $\mathrm{K}+$ channel profile of microglia at immunologically defined functional states. Neuroscience. 1995;64(1): 183-91. [PMID: 7535902]

56. Schilling T, Quandt FN, Cherney VV, Zhou W, Heinemann U, DeCoursey TE, Eder C. Upregulation of Kv1.3 $\mathrm{K}(+)$ channels in microglia deactivated by TGF-beta. Am J Physiol Cell Physiol. 2000;279(4):C1123-34. [PMID: 11003593]

57. Mullen K, Rozycka M, Rus H, Graber J, Pennington M, Judge S, Calabresi P. Maturation of dendritic cells is marked by functionally relevant expression of $\mathrm{K}+$ channels Kv1.5 and Kv1.3 [abstract]. Johns Hopkins Medical Institute Rare Neuroimmunologic Disorders Symposium. 2004 Aug 18-22; Baltimore (MD).

58. Kotecha SA, Schlichter LC. A Kv1.5 to Kv1.3 switch in endogenous hippocampal microglia and a role in proliferation. J Neurosci. 1999;19(24):10680-93. [PMID: 10594052]

59. Cepok S, Rosche B, Grummel V, Vogel F, Zhou D, Sayn J, Sommer N, Hartung HP, Hemmer B. Short-lived plasma blasts are the main $\mathrm{B}$ cell effector subset during the course of multiple sclerosis. Brain. 2005;128(Pt 7):1667-76. [PMID: 15800022]

60. Genain CP, Cannella B, Hauser SL, Raine CS. Identification of autoantibodies associated with myelin damage in multiple sclerosis. Nat Med. 1999;5(2):170-75.

[PMID: 9930864]

61. Lucchinetti C, Bruck W, Parisi J, Scheithauer B, Rodriguez M, Lassmann H. Heterogeneity of multiple sclerosis lesions: Implications for the pathogenesis of demyelination. Ann Neurol. 2000;47(6):707-17. [PMID: 10852536$]$
62. Reindl M, Linington C, Brehm U, Egg R, Dilitz E, Deisenhammer F, Poewe W, Berger T. Antibodies against the myelin oligodendrocyte glycoprotein and the myelin basic protein in multiple sclerosis and other neurological diseases: A comparative study. Brain. 1999;122(Pt 11): 2047-56. [PMID: 10545390]

63. Storch MK, Piddlesden S, Haltia M, Iivanainen M, Morgan P, Lassmann $\mathrm{H}$. Multiple sclerosis: In situ evidence for antibody- and complement-mediated demyelination. Ann Neurol. 1998;43(4):465-71. [PMID: 9546327]

64. Bruck W, Neubert K, Berger T, Weber JR. Clinical, radiological, immunological and pathological findings in inflammatory CNS demyelination-possible markers for an antibody-mediated process. Mult Scler. 2001;7(3):173-77. [PMID: 11475441]

65. Berger T, Rubner P, Schautzer F, Egg R, Ulmer H, Mayringer I, Dilitz E, Deisenhammer F, Reindl M. Antimyelin antibodies as a predictor of clinically definite multiple sclerosis after a first demyelinating event. N Engl J Med. 2003;349(2):139-45. [PMID: 12853586]

66. Lim ET, Berger T, Reindl M, Dalton CM, Fernando K, Keir G, Thompson EJ, Miller DH, Giovannoni G. Antimyelin antibodies do not allow earlier diagnosis of multiple sclerosis. Mult Scler. 2005;11(4):492-94. [PMID: 16042235]

67. Choquet D, Korn H. Modulation of voltage-dependent potassium channels in B lymphocytes. Biochem Pharmacol. 1988;37(20):3797-3802. [PMID: 3056414]

68. Choquet D, Sarthou P, Primi D, Cazenave PA, Korn H. Cyclic AMP-modulated potassium channels in murine B cells and their precursors. Science. 1987;235(4793): 1211-14. [PMID: 2434998]

69. Amigorena S, Choquet D, Teillaud JL, Korn H, Fridman WH. Ion channel blockers inhibit B cell activation at a precise stage of the G1 phase of the cell cycle. Possible involvement of $\mathrm{K}+$ channels. J Immunol. 1990;144(6): 2038-45. [PMID: 2313087]

70. Brent LH, Butler JL, Woods WT Jr, Bubien JK. Transmembrane ion conductance in human B lymphocyte activation. J Immunol. 1990;145(8):2381-89. [PMID: 1698853]

71. Partiseti M, Choquet D, Diu A, Korn H. Differential regulation of voltage- and calcium-activated potassium channels in human B lymphocytes. J Immunol. 1992;148(11): 3361-68. [PMID: 1588037]

72. Partiseti M, Korn H, Choquet D. Pattern of potassium channel expression in proliferating B lymphocytes depends upon the mode of activation. J Immunol. 1993;151(5): 2462-70. [PMID: 8360473]

73. Spencer RH, Chandy KG, Gutman GA. Immunological identification of the Shaker-related Kv1.3 potassium channel protein in $\mathrm{T}$ and $\mathrm{B}$ lymphocytes, and detection of related proteins in flies and yeast. Biochem Biophys Res Commun. 1993;191(1):201-6. [PMID: 8447822] 
74. Sutro JB, Vayuvegula BS, Gupta S, Cahalan MD. Voltage sensitive ion channels in human B lymphocytes. Adv Exp Med Biol. 1989;254:113-22. [PMID: 2816543]

75. Wulff H, Knaus HG, Pennington M, Chandy KG. K+ channel expression during B cell differentiation: Implications for immunomodulation and autoimmunity. J Immunol. 2004;173(2):776-86. [PMID: 15240664$]$

76. Spencer RH, Sokolov Y, Li H, Takenaka B, Milici AJ, Aiyar J, Nguyen A, Park H, Jap BK, Hall JE, Gutman GA, Chandy KG. Purification, visualization, and biophysical characterization of Kv1.3 tetramers. J Biol Chem. 1997; 272(4):2389-95. [PMID: 8999950]

77. Rus H, Pardo CA, Hu L, Darrah E, Cudrici C, Niculescu T, Niculescu F, Mullen KM, Allie R, Guo L, Wulff H, Beeton C, Judge SI, Kerr DA, Knaus HG, Chandy KG, Calabresi PA. The voltage-gated potassium channel Kv1.3 is highly expressed on inflammatory infiltrates in multiple sclerosis brain. Proc Natl Acad Sci USA. 2005;102(31):11094-99. [PMID: 16043714$]$

78. Judge SI, Paterson PY, Mannie MD, Yeh JZ. Modulation of outward $\mathrm{K}(+)$ conductance is a post-activational event in rat $\mathrm{T}$ lymphocytes responsible for the adoptive transfer of experimental allergic encephalomyelitis. J Biomed Sci. 1997;4(2-3):98-110. [PMID: 11725140]

79. Kalman K, Pennington MW, Lanigan MD, Nguyen A, Rauer H, Mahnir V, Paschetto K, Kem WR, Grissmer S, Gutman GA, Christian EP, Cahalan MD, Norton RS, Chandy KG. ShK-Dap22, a potent Kv1.3-specific immunosuppressive polypeptide. J Biol Chem. 1998;273(49): 32697-707. [PMID: 9830012]

80. Judge SI, Yeh JZ, Mannie MD, Seifert LP, Paterson PY. Potassium channel blockers inhibit adoptive transfer of experimental allergic encephalomyelitis by myelinbasicprotein-stimulated rat T lymphocytes. J Biomed Sci. 1997;4(4):169-78. [PMID: 11725150]

81. Wulff H, Calabresi PA, Allie R, Yun S, Pennington M, Beeton C, Chandy KG. The voltage-gated Kv1.3 K(+) channel in effector memory $\mathrm{T}$ cells as new target for MS. J Clin Invest. 2003;111(11):1703-13. [PMID: 12782673]

82. Vennekamp J, Wulff H, Beeton C, Calabresi PA, Grissmer S, Hansel W, Chandy KG. Kv1.3-blocking 5-phenylalkoxypsoralens: A new class of immunomodulators. Mol Pharmacol. 2004;65(6):1364-74. [PMID: 15155830]

83. Wulff H, Miller MJ, Hansel W, Grissmer S, Cahalan MD, Chandy KG. Design of potent and selective inhibitor of the intermediate-conductance Ca2+-activated, IKCa1: A potential immunosuppressant. Proc Natl Acad Sci USA. 2000;97(14):8151-56. [PMID: 10884437]

84. Gallucci S, Lolkema M, Matzinger P. Natural adjuvants: Endogenous activators of dendritic cells. Nat Med. 1999; 5(11):1249-55. [PMID: 10545990]
85. Sallusto F, Lanzavecchia A. Efficient presentation of soluble antigen by cultured human dendritic cells is maintained by granulocyte/macrophage colony-stimulating factor plus interleukin 4 and downregulated by tumor necrosis factor alpha. J Exp Med. 1994;179(4):1109-18. [PMID: 8145033]

86. Cleveland DW, Rothstein JD. From Charcot to Lou Gehrig: Deciphering selective motor neuron death in ALS. Nat Rev Neurosci. 2001;2(11):806-19. [PMID: 11715057$]$

87. Drachman DB, Frank K, Dykes-Hoberg M, Teismann P, Almer G, Przedborski S, Rothstein JD. Cyclooxygenase 2 inhibition protects motor neurons and prolongs survival in a transgenic mouse model of ALS. Ann Neurol. 2002; 52(6):771-78. [PMID: 12447931]

88. Zhu S, Stavrovskaya IG, Drozda M, Kim BY, Ona V, Li M, Sarang S, Liu AS, Hartley DM, Wu du C, Gullans S, Ferrante RJ, Przedborski S, Kristal BS, Friedlander RM. Minocycline inhibits cytochrome c release and delays progression of amyotrophic lateral sclerosis in mice. Nature. 2002;417(6884):74-78. [PMID: 11986668$]$

89. Hoffman PM, Cimino EF, Robbins DS, Broadwell RD, Powers JM, Ruscetti SK. Cellular tropism and localization in the rodent nervous system of a neuropathogenic variant of Friend murine leukemia virus. Lab Invest. 1992;67(3):314-21. [PMID: 1405490]

90. Wilt SG, Yiannoulos GC, Smarik J, Ruscetti SK. Minocyline delays onset and microglial activation in a rat retroviral neuroinflammatory disease. Program No. 103.10. 2003 Abstract Viewer/Itinerary Planner. Washington (DC): Society for Neuroscience, 2003.

91. Schluesener HJ, Seid K, Kretzschmar J, Meyermann R. Leukocyte chemotactic factor, a natural ligand to CD4, is expressed lymphocytes and microglial cells of the MS plaque. J Neurosci Res. 1996;44(6):606-11. [PMID: 8794952]

92. Ulvestad E, Williams K, Vedeler C, Antel J, Nyland H, Mork S, Matre R. Reactive microglia in multiple sclerosis lesions have an increased expression of receptors for the Fc part of IgG. J Neurol Sci. 1994;121(2):125-31. [PMID: 8158203]

93. Trapp BD, Bo L, Mork S, Chang A. Pathogenesis of tissue injury in MS lesions. J Neuroimmunol. 1999;98(1): 49-56. [PMID: 10426362]

94. Bagasra O, Michaels FH, Zheng YM, Bobroski LE, Spitsin SV, Fu ZF, Tawadros R, Koprowski H. Activation of the inducible form of nitric oxide synthase in the brains of patients with multiple sclerosis. Proc Natl Acad Sci USA. 1995;92(26):12041-45. [PMID: 8618840]

95. Bo L, Dawson TM, Wesselingh S, Mork S, Choi S, Kong PA, Hanley D, Trapp BD. Induction of nitric oxide synthase in demyelinating regions of multiple sclerosis brains. Ann Neurol. 1994;36(5):778-86. [PMID: 7526776] 
96. Cross AH, Manning PT, Keeling RM, Schmidt RE, Misko TP. Peroxynitrite formation within the central nervous system in active multiple sclerosis. J Neuroimmunol. 1998;88(1-2):45-56. [PMID: 9688323]

97. Giovannoni G, Heales SJ, Silver NC, O’Riordan J, Miller RF, Land JM, Clark JB, Thompson EJ. Raised serum nitrate and nitrite levels in patients with multiple sclerosis. J Neurol Sci. 1997;145(1):77-81. [PMID: 9073032]

98. Johnson AW, Land JM, Thompson EJ, Bolanos JP, Clark JB, Heales SJ. Evidence of increased nitric oxide production in multiple sclerosis. J Neurol Neurosurg Psychiatry. 1995;58(1):107. [PMID: 7823050]

99. Yamashita T, Ando Y, Obayashi K, Uchino M, Ando M. Changes in nitrite and nitrate (NO2-/NO3-) levels in cerebrospinal fluid of patients with multiple sclerosis. J Neurol Sci. 1997;153(1):32-34. [PMID: 9455975]

100. Redford EJ, Kapoor R, Smith KJ. Nitric oxide donors reversibly block axonal conduction: Demyelinated axons are especially susceptible. Brain. 1997;120(Pt 12):2149-57. [PMID: 9448570]

101. Smith KJ, Kapoor R, Hall SM, Davies M. Electrically active axons degenerate when exposed to nitric oxide. Ann Neurol. 2001;49(4):470-76. [PMID: 11310624]
102. Lee J, Judge S, Dugger N, Li Z, Hoffman P. Role of potassium channels in microglial activation [abstract]. Presented at Department of Veterans Affairs Maryland Healthcare System, Baltimore (MD), April 24, 2003.

103. Benveniste EN. Role of macrophages/microglia in multiple sclerosis and experimental allergic encephalomyelitis. J Mol Med. 1997;75(3):165-73. [PMID: 9106073]

104. Gonzalez-Scarano F, Baltuch G. Microglia as mediators of inflammatory and degenerative diseases. Annu Rev Neurosci. 1999;22:219-40. [PMID: 10202538]

105. Hickey WF. Migration of hematogenous cells through the blood-brain barrier and the initiation of CNS inflammation. Brain Pathol. 1991;1(2):97-105. [PMID: 1669702]

106. Beeton C, Pennington MW, Wulff H, Singh S, Nugent D, Crossley G, Khaytin I, Calabresi PA, Chen CY, Gutman GA, Chandy KG. Targeting effector memory T cells with a selective peptide inhibitor of Kv1.3 channels for therapy of autoimmune diseases. Mol Pharmacol. 2005;67(4): 1369-81. [PMID: 15665253]

Submitted for publication September 1, 2004. Accepted in revised form February 8, 2005. 